\title{
DIALEKTIKA PLURALISME HUKUM: Upaya Penyelesaian Masalah Ancaman Keberagaman dan Keberagamaan di Indonesia
}

\author{
Novita Dewi Masyithoh \\ Universitas Diponegoro Semarang \\ e-mai: novita.dewi79@yahoo.co.id
}

\begin{abstract}
Conflict resolution on SARA requires pluralistic approaches. Hence, the presence of legal pluralism becomes a new approach to resolve the problem. This study is a qualitative research that convey three dimensions of legal pluralism, namely natural law, state law and society law. The study used secondary data, with primary and secondary legal materials obtained by documentation resources. Data were analyzed inductively, used the contemporary theories to produce more conceptual and general propositions for conclusions and recommendations. The result shows that there have been 8 cases on SARA conflict in Indonesia during the last three years. To solve these problems, religious leaders can use natural law approach to reinternalize religious values and tolerance. In addition, the government also should understand that those conflicts were a form of society law owing to discreditable law society and religious diversity. Therefore, non penal policy with persuasive appeals is needed to reduce the problems. However, penal policy through law enforcement should also be implemented as a form of state positivism law. In other words, state positivism law should go hand in hand with natural law and society law in order to reach the best decision based on moral and religious ethics as well as social values.
\end{abstract}

$* * *$

Penyelesaian konflik SARA membutuhkan pendekatan-pendekatan yang plural. Oleh karena itu pluralisme hukum hadir sebagai pendekatan baru untuk menyelesaikan tersebut Penelitian ini adalah penelitian hukum dengan tradisi kualitatif yang berusaha mendialektikakan 3 dimensi dari legal pluralism, yaitu natural law, state law dan law society. Penelitian menggunakan data sekunder, dengan bahan hukum primer dan sekunder yang diperoleh dengan teknik dokumentasi. Data dianalisis secara induktif dengan menggunakan teori-teori yang ada untuk memproduksi suatu proposisi yang umum, sehingga menghasilkan kesimpulan dan rekomendasi. Hasil penelitian menunjukkan bahwa telah terjadi 8 konflik SARA di Indonesia dalam 3 tahun terakhir. Untuk memecahkan masalah tersebut, para pemuka agama menggunakan pendekatan natural law untuk reinternaliasasi nilainilai keluhuran atas agama dan toleransi. Pemerintah seharusnya memahami bahwa konflik tersebut adalah bentuk society law karena tercederainya keragaman dan keberagamaan. Perlu kebijakan non penal dengan seruan-seruan persuasif agar persoalan serupa tidak lagi terjadi. Di sisi lain, kebijakan penal melalui penegakan hukum juga harus dilakukan, sebagai bentuk state positivism law. State positivism law harus mampu menggandeng natural law dan law society, agar diperoleh putusan terbaik yang berlandaskan nilai-nilai moral ethic religion dan nilai-nilai sosial kemasyarakatan.

Keywords: legal pluralism; diversity; religiousity 


\section{A. Pendahuluan}

Indonesia adalah negara kesatuan dengan karakteristik kebangsaan yang sangat plural. Terdiri dari berbagai pulau, suku bangsa, agama dan budaya. Di satu sisi, keberagaman ini dapat dipandang sebagai suatu kekuataan, namun di sisi lain juga dapat dipandang sebagai suatu kelemahan. keberagaman akan menjadi suatu kekuatan manakala dengan adanya keberagaman mampu mewujudkan perasaan kebangsaan dan persatuan. Sebaliknya, keberagaman akan menjadi suatu bencana, manakala benih-benih sukuisme dan radikalisme agama telah muncul dan bersemayam dalam suatu kelompok agama, suku/ etnis dan keyakinan.

Sejak berikrar satu tanah air, tanah air Indonesia, satu bangsa, bangsa Indonesia dan satu bahasa, bahasa Indonesia, kita telah mewujudkan satu persatuan dan kesatuan. Namun akhir-akhir ini keharmonisan kehidupan berbangsa dan beragama telah terusik karena adanya benturan-benturan yang membawa persoalan agama dan etnis. Aksi-aksi terorisme, fanatisme dan radikalisme paham keagamaan sangat marak di Indonesia. ${ }^{1}$ Keinginan untuk membentuk negara daulah Islam banyak didengung-dengungkan sebagai anomali antidemokrasi yang ada di dunia, termasuk di Indonesia. Banyak generasi muda dan mahasiswa yang direkrut secara masif melalui media-media online dan kelompok-kelompok ekstrem yang dibentuk dalam skala kecil, sehingga banyak yang bersedia menjadi 'pengantin' pelaku bom bunuh diri. Jihad banyak diklaim sebagai penyebab lunturnya nasionalisme kebangsaan.

Selanjutnya adalah persoalan-persoalan sensitif SARA yang marak terjadi akhir-akhir ini. Sebagaimana banyaknya aksi protes atas pernyataan Ahok, Gubernur DKI Jakarta saat melakukan kunjungan dinas di Kepulauan Seribu pada tanggal 28September 2016. ${ }^{2}$ Ahok yang saat ini tengah mencalonkan diri di ajang kontestasi Pilkada DKI Jakarta menyatakan, "Jangan mau dibohongi pakai surat

\footnotetext{
${ }^{1}$ Realitasnya, teorisme di Indonesia telah ada sejak zaman Presiden Soekarno yang pernah hendak dibunuh pada tahun 1962 dan berhasil digagalkan. Namun sejak tahun 1981, terorisme mulai diklaim bernuansa jihad keagamaan. Lihat: J. Indowan Seto Wahyu Wibowo, "Representasi Terorisme di Indonesia dalam Pemberitaan Media Massa: Kritik Pemberitaan Terorisme pada Koran Tempo 2010", Disertasi, tidak diterbitkan (Jakarta: Fakultas Ilmu Sosial dan Ilmu Politik, Universitas Indonesia, 2014), h. $10-16$.
}

${ }^{2}$ https://www.youtube.com/watch?v=dkeOkOmd6_Y. diunduh tanggal 19 Oktober 2016. 
al-Maidah51". ${ }^{3}$ Pernyataan tersebut dinilai telah menistakan agama Islam dan para ulama. Majelis Ulama Indonesia (MUI) telah menyampaikan pendapat dan sikap keagamaan yang disampaikan pada tanggal 11 Oktober 2016. ${ }^{4}$ Pernyataan tersebut bukan hanya menyulut kemarahan umat Islam, namun juga membawabawa isu gerakan anti Cina, karena Ahok adalah etnis Cina di Indonesia. Persoalan menjadi sangat complicated karena bersamaan dengan memanaskan suhu politik menjelang Pilkada di Jakarta. Dinilai banyak kepentingan yang turut mengobokobok persoalan ini, yang dinilai untuk menumbangkan lawan dan mengunggulkan popularitas calon lainnya.

Persoalan SARA seringkali muncul karena kesenjangan dan ketidakharmonisan dalam kehidupan sosial, ekonomi dan politik. Banyak pusat-pusat ekonomi yang saat ini sudah mulai dikuasai oleh asing dan dinilai menjajah warga pribumi, sebagai warga mayoritas banyak yang menjadi kuli di negeri sendiri. Pemerataan ekonomi tidak mampu menyentuh masyarakat lapisan bawah di berbagai daerah. Dinamika perpolitikan pun diklaim membawa andil bagi kemerosotan nasionalisme bangsa. Kebijakan politik dianggap berpihak pada kepentingan kelompok segelintir orang yang mampu mempengaruhi kekuasaan. Masyarakat kecil merasa menjadi korban sehingga muncul apatisme terhadap kepemimpinan negara.

Hukum yang dianggap sebagai garda terdepan untuk meregulasikan kebijakan dan pengaturan atas kerukunan hidup dipertaruhkan bahkan diragukan kemampuannya menyelesaikan persoalan ini dengan adil dan tuntas. Berdasarkan pendekatan normatif (normologi), hukum telah dinilai gagal menyelesaikan persoalan ini. Terbitnya Undang-Undang No. 15 Tahun 2003 tentang Pemberantasan Tindak Pidana Terorisme, Peraturan Bersama Menteri Agama dan Menteri Dalam Negeri No. 8 dan 9 Tahun 2006 tentang Pedoman Pelaksanaan Tugas Kepala Daerah/Wakil Kepala Daerah dalam Pemeliharaan Kerukunan Umat Beragama, Pemberdayaan Forum Kerukunan Umat Beragama dan Pendirian Rumah Ibadat dinilai belum mampu menyelesaikan persoalan SARA sampai ke akar-akarnya.

\footnotetext{
${ }^{3}$ https://www.intelijen.co.id/lakukan-penistaan-agama-muhammadiyah-segera-polisikan-ahok/. diunduh 19 Oktober 2016,

${ }^{4}$ http://berita.islamedia.id/2016/10/inilah-fatwa-lengkap-mui-ahok-terbukti-menghina-alquranulama.html. diunduh 19 Oktober 2016.
} 
Hukum dituntut berperan melampaui batas normativitas peraturan, sehingga dapat menyentuh akar persoalan, mengapa persoalan SARA ini muncul dan bagaimana menyelesaikannya menggunakan jalur-jalur non hukum. Pendekatan interdisipliner dan pluralistik diperlukan, karena persoalan SARA tidak hanya dapat diobati hanya oleh penegakan hukum positif, namun juga dengan resolusi kegamaan dan sosial. Pluralisme hukum (legal pluralism) adalah salah satu pendekatan yang ditawarkan, untuk mengurai persoalan keberagaman dan keberagamaan. Pluralisme hukum menawarkan suatu model berfokus pluralitas untuk memahami hukum dengan mempertimbangkan tiga elemen pokok, yaitu natural law (ethic/moral/religion), positive law, dan socio-legal. Terdapat interaksi yang konstan di antara tiga elemen tersebut. $^{5}$

Pancasila sebagai staatsfundamentalnorm sekaligus rechtsidee ditempatkan sebagai landasan ethic/moral/religion dalam natural law. Dengan ditetapkannya Pancasila sebagai grundnorm, maka Pancasila menjadi landasan filosofis keberlakuan seluruh peraturan perundang-undangan di Indonesia. State Positive Law adalah peraturan perundang-undangan negara yang dijadikan dasar pengaturan tentang persoalan-persoalan SARA. Law Society, diperlukan sebagai suatu pendekatan yang mengkombinasikan pendekatan normatif (normologic) dan pendekatan sosiologis (normologic). ${ }^{6}$ Dengan demikian, dialektika antara moral ethic religion, normologic dan nomologic diharapkan dapat menjawab persoalan ancaman atas keragaman dan keberagamaan yang dialami bangsa ini.

Permasalahan yang akan dibahas adalah bagaimana dialektika moral /ethic/religion, state positivism dan socio-legal mampu menyelesaikan persoalan ancaman keberagaman dan keberagamaan agar terjadi harmonisasi atas keragaman dan keberagamaan.

Penelitian ini adalah penelitian hukum dengan tradisi kualitatif. Tradisi penelitian kualitatif merupakan tradisi penelitian yang menaungi berbagai metode dan membungkusnya dalam sejumlah strategi yang diambil dari

\footnotetext{
${ }^{5}$ Werner Menski, Perbandingan Hukum dalam Konteks Global; Sistem Eropa, Asia dan Afrika, terj. (Bandung: Nusa Media, 2015), h. 244-247.

6Bernard Arief Sidharta, Ilmu Hukum Indonesia, Upaya Pengembangan Ilmu Hukum Sistematikyang Responsifterhadap Perubahan Masyarakat (Yogyakarta: Genta Publishing, 2013), h. 76.
} 
serangkaian asumsi yang saling berhubungan dan bersifat khas.7 Menggunakan tradisi kualitatif karena dalam penelitian ini berusaha mendialektikakan 3 hal berbeda, yaitu moral ethic religion, normologic dan nomologic, sebagaimana disampaikan oleh Denzin dan Lincoln yang menyatakan bahwa penelitian kualitatif merupakan bidang antar disiplin, lintas disiplin dan kadang-kadang kontra disiplin. ${ }^{8}$

Metode pendekatan yang digunakan adalah legal pluralism approach ${ }^{9}$ yang berusaha mengkombinasikan 3 pendekatan, yaitu moral/ethic/religion, state positivism dan socio-legal approach. Data yang digunakan dalam penelitian ini adalah data sekunder ${ }^{10}$ diperoleh dengan dokumentasi atas hasil-hasil penelitian, jurnal dan tulisan ilmiah lainnya, liputan-liputan berita serta bahan hukum. Bahan hukum yang digunakan adalah bahan hukum primer ${ }^{11}$ dan bahan hukum sekunder.12 Bahan hukum primer yang digunakan adalah Pancasila, UUD 1945 dan sejumlah peraturan perundang-undangan. Sedangkan bahan hukum sekunder yang digunakan adalah adalah kamus hukum.

\footnotetext{
${ }^{7}$ A. Chaedar Alwasilah, Pokoknya Kualitatif: Dasar-dasar Merancang dan Melakukan Penelitian Kualitatif(Bandung: Dunia Pustaka Jaya, 2012), h. xxiv.

8Norman K. Denzin \& Yvonna S. Lincoln, Handbook of Qualitative Research, edisi terj. (Yogyakarta: Pustaka Pelajar, 2009),h. 3-4.

${ }^{9}$ Legal pluralism approach disampaikan oleh Werner Menski pada saat melakukan penelitian tentang perbandingan hukum di negara-negara Asia dan Afrika. Ia menemukan adanya perbedaan hukumdi Barat (Eropa) dan di Asia. Eropa sebagai kiblat hukum modern, menggunakan cara berhukum yang berdasarkan state law dan tidak dipengaruhi oleh unsur-unsur non hukum, seperti agama dan moral. Berbeda dengan negara-negara di Asia yang masyarakatnya sangat pluralistik dan prismatik, di mana hukum adat dan agama masih digunakan, maka cara berhukumnya masih menggunakan pendekatan moral, ethic dan agama yang tergabung dalam natural law. Lihat Werner Menski, Comparative Law in A Global Context (The Legal System of Asia and Africa), Second Edition, (UK: Cambridge University Press, 2006), h. 187.

${ }^{10}$ Data sekunder adalah data yang diperoleh atau dikumpulkan oleh peneliti berasal dari sumbersumber yang telah ada dan diolah. Lexy J. Moleong, Metodologi Penelitian Kualitatif (Bandung: Remaja Rosdakarya, 2004), h. 157.

${ }^{11}$ Bahan-bahan hukum primer adalah semua aturan hukum yang dibentuk dan/atau dibuat secara resmi oleh suatu lembaga negara dan/atau badan-badan pemerintahan, yang demi tegaknya akan diupayakan berdasarkan daya paksa yang dilakukan secara resmi pula oleh aparat negara. Soetandyo Wignjosoebroto, "Penelitian Hukum dan Hakikatnya Sebagai Penelitian Ilmiah", dalam Sulistyowati Irianto dan Sidharta, Metode Penelitian Hukum, Konstelasi dan Refleksi (Jakarta: Yayasan Obor Indonesia, 2009).h. h. 68-69.

${ }^{12}$ Bahan-bahan hukum sekunder adalah seluruh informasi tentang hukum yang berlaku atau yang pernah berlaku di suatu negara, di antaranya adalah buku-buku, laporan penelitian, jurnal, karya ilmiah yang dipublikasi atau tidak dipublikasikan, dan lain sebagainya yang memilik daya persuasif dalam pembentukan hukum. Ibid.
} 
Data-data yang telah diperoleh selanjutnya direduksi dan dirangkum, dipilih berdasarkan keutamaan data yang terpenting sesuai dengan permasalahan yang ada. Data-data tersebut dikategorisasikan, dihubungankan dan diperbandingkan untuk selanjutnya dilakukan interpretasi. ${ }^{13}$ Data-data yang reliabel dimasukkan ke dalam kerangka analisis yang sudah disusun dalam kerangka teori untuk membantu mempertajam analisis. ${ }^{14}$ Data-data yang telah diinterpretasi dianalisis secara induktif dan ditarik menuju konsep yang lebih abstrak, dengan menggunakan teori-teori yang ada untuk memproduksi suatu proposisi yang lebih abstrak dan umum, sehingga menghasilkan rekomendasi.

\section{B. Upaya Penyelesaian Masalah atas Ancaman Keberagaman dan Keberagamaan di Indonesia}

\section{Beberapa Kajian tentang Keberagaman dan Keberagamaan di Indonesia}

Penelitian dan tulisan ilmiah tentang keberagaman dan keberagamaan sudah banyak dilakukan, karena persoalan tersebut akan terus ada seiring dengan perkembangan masyarakatnya. Namun permasalahan keberagaman dan keberagamaan yang menggunakan pendekatan legal pluralism ini masih belum banyak digunakan. Penelitian dan tulisan ilmiah yang telah ada di antaranya adalah: Pertama, Ita Mutiara Dewi, "Nasionalisme dan Kebangkitan dalam Teropong", Jurnal Mozaik, Vol. 3 No. 3, Tahun 2008. Tulisan ini merenungkan kembali tentang nasionalisme sebagai unsur pembangkit khususnya di negerinegeri Muslim. Hal ini disebabkan Dunia Barat dan Islam mempunyai standar yang khas yang berbeda dalam mengukur sesuatu. Standar Barat yang lekat dengan sekulerisme adalah ketika hal tersebut bermanfaat diambil, ketika dianggap tidak bermanfaat tidak diambil sehingga sangat mudah terjadi relativitas, kebingungan dan dapat menciptakan konflik baru karena relativitas tadi, pendapat masing-masing orang dapat berbeda. Jadi jika Islam memang tidak selaras dengan konsep nasionalisme bukan berarti harus dikompromikan dan

\footnotetext{
${ }^{13}$ Abbas Tashakkori dan Charles Tedlie, Mixed Methodology: Mengkombinasikan Pendekatan Kualitatifdan Kuantitatif(Yogyakarta: Pustaka Pelajar), h. 67-68.

${ }^{14}$ Norman K. Denzin dan Yvonna S. Lincoln, Handbook of Qualitative Research, h. 670.
} 
dipaksakan dengan berbagai cara agar sesuai. Hal yang menjadi perenungan bersama adalah apakah dengan ruang lingkup nasionalistik, Indonesia dan negara-negara lain yang pernah tergabung dalam wilayah Islam dapat menghadapi masalah Palestina serta kaum muslimin di belahan dunia lain?15

Kedua, Yudi Latif, "Revitalisasi Pancasila di Tengah Dua Fundamentalisme", Jurnal Dignitas, Vol. VII, No. 2 Tahun 2011. Tulisan ini menjelaskan tentang perlunya penyegaran pemahaman dan aktualisasi nilai-nilai Pancasila untuk menangkal berjangkitnya beragam ancaman ekstremisme. Dengan menguatkan nilai-nilai ketuhanan yang berkebudayaan, kebangsaan yang berperikemanusiaan, serta demokrasi permusyawaratan yang berorientasi keadilan sosial, Indonesia akan mampu menghadapi perkembangan baru dengan suatu visi global yang berkearifan lokal. Dalam konteks ini, yang diperlukan adalah "radikalisasi Pancasila". "Radikalisasi" dalam arti ini adalah pengakaran ideologi, demi membuat Pancasila tegar, efektif, dan menjadi petunjuk bagaimana negara ini ditata-kelola dengan benar. ${ }^{16}$

Ketiga, Mifdal Zusron Alfaqi, "Memahami Indonesia Melalui Prespektif Nasionalisme, Politik Identitas, Serta Solidaritas", Jurnal Pendidikan Pancasila dan Kewarganegaraan, Vol. 28, No. 2, Agustus 2015. Tulisan ini membahas tentang adanya politik identitas yang ada di dalam nasionalisme Indonesia. Politik identitas yang ada disetiap suku ada bermacam corak dan latar belakang sendirisendiri, mulai dari kemunculan politik identitas yang di sebabkan oleh adanya ketidakadilan, wujud perlawanan, warisan nilai luhur, serta alat untuk menunjukkan jati diri suku tertentu dengan suku lain. Politik identitas yang ada di Indonesia yang begitu beragam tersebut harus diperhatikan oleh pemerintah Indonesia supaya adanya politik identitas kesukuan tersebut tidak mengganggu semangat nasionalisme. Akan tetapi adanya politik identitas tersebut bisa menguatkan nasionalisme yang ada di Indonesia dengan bentuk politik identitas nasional yang menjunjung tinggi nilai persatuan dan kesatuan dalam kebhinekaan. Kemudian sikap nasionalisme dan politik identitas harus dibarengi dingan sikap solidaritas

\footnotetext{
15Ita Mutiara Dewi, "Nasionalisme dan Kebangkitan dalam Teropong", Jurnal Mozaik, Vol. 3 No. 3 , 2008, h. 14-19.

16Yudi Latif, "Revitalisasi Pancasila di Tengah Dua Fundamentalisme”, Jurnal Dignitas, Vol. VII, No. 2 2011, h. 79-80.
} 
kebangsaan yang kuat. Sikap solidaritas kebangsaan yang kuat akan melahirkan tatanan masyarakat yang stabil dan saling menghargai serta merasa memiliki individu satu dengan individu yang lainnya. ${ }^{17}$

\section{Dialektika Pluralisme Hukum: Upaya Penyelesaian Konflik Bernuansa SARA}

Berdasarkan Laporan dari Kesbangpol Kemendagri pada Tahun 2013, 2014 dan Kuartal 2015 (medio kuartal Januari s/d April) data konflik SARA ${ }^{18}$ yang terjadi di Indonesia terdapat dalam Tabel 1.

Tabel 1.

Jumlah Konflik SARA di Indonesia Tahun 2013, 2014 dan 2015

\begin{tabular}{|c|l|c|}
\hline No & \multicolumn{1}{|c|}{ Tahun } & Jumlah konflik \\
\hline 1 & 2013 & 8 \\
\hline 2 & 2014 & 1 \\
\hline 3 & 2015 (Medio Januari-April) & 0 \\
\hline
\end{tabular}

Sumber: Kesbangpol Kemendagri 2015

Data di atas menjelaskan bahwa ada penurunan angka konflik SARA di Indonesia dari tahun 2013 sampai tahun 2015. Semua konflik SARA yang ada tersebut ditangani oleh hukum dan dilakukan rekonsiliasi secara terus menerus, sehingga benih-benih SARA yang mungkin masih ada diminimalisir untuk tumbuh kembali.

Negara Kesatuan Republik Indonesia (NKRI) adalah negara yang dipersatukan karena keberagaman dan keberagamaan. Keberagaman suku, bahasa, adat istiadat dan budaya adalah kekuataan pemersatu bangsa. Demikian juga dengan keberagamaan telah memberikan warna, bahwa Indonesia adalah negara yang berdasarkan Ketuhanan Yang Maha Esa, sebagaimana disampaikan oleh Arief Hidayat sebagai religious nation state. ${ }^{19}$ Dengan demikian, konse-

17Mifdal Zusron Alfaqi, "Memahami Indonesia Melalui Prespektif Nasionalisme, Politik Identitas, Serta Solidaritas", Jurnal Pendidikan Pancasila dan Kewarganegaraan, Vol. 28, No. 2, Agustus 2015.

18Data dari Kesbangpol Kementrian Dalam Negeri Tahun 2013, 2014 dan kuartal 2015. http://kesbangpol.kemendagri.go.id/files_uploads/Data_Konflik.pdf.

${ }^{19}$ Religious Nation State terbangun atas adanya hubungan antara negara dan agama dalam bingkai Pancasila, yang tidak menganut sekulerisme, tetapi juga bukan negara agama. Disebut juga dengan konsep negara hukum Pancasila adalah sebuah konsep negara yang berketuhanan yang berarti bahwa kehidupan berbangsa dan bernegara Indonesia berdasarkan atas kepercayaan kepada Ketuhanan Yang 
kuensi logis dari pilihan keberagamaan adalah bahwa atheisme dan komunisme dilarang keras hidup di Indonesia, karena keduanya telah mengesampingkan Ketuhanan Yang Maha Esa.

Keberagaman dan keberagamaan dalam Negara Kesatuan Republik Indonesia adalah bentuk kebhinnekaan yang selama ini memperkokoh jiwa kebangsaan, persatuan dan kesatuan bangsa. Indonesia dikenal sebagai negara yang memiliki toleransi keragaman dan keberagamaan yang kuat serta tidak mudah dipecah belah. Nilai-nilai kebhinnekaan itu telah tertanam sejak 'Nusantara' dipersatukan atas Sumpah Mahapatih Gajah Mada di bawah kejayaan Kerajaan Majapahit. Kejayaan Majapahit berhasil mempersatukan Nusantara, karena kekuatan religio magis yang berpusat pada Sang Raja, adanya ikatan sosial kekeluargaan antara kerajaan-kerajaan daerah di Jawa dengan Sang Raja dalam lembaga Pahom Narendra, ${ }^{20}$ adanya ikatan ekonomis berupa persembahan upeti dalam pisowanan agung untuk pejabat-pejabat daerah di Jawa dan pemungutan pajak, dan adanya kekuatan militer yang dikoordinasi oleh Apatih Mangkubumi Gadjah Mada. ${ }^{21}$

Masuknya kolonialisme di Indonesia semakin mengokohkan jiwa persatuan dan kesatuan untuk membela negara mengusir penjajah dari bumi Indonesia. Generasi muda dari Sabang sampai Merauke telah berikrar satu tanah air, satu bangsa dan satu bahasa yang diucapkan pada tanggal 28 Oktober 1928 yang disebut dengan Sumpah Pemuda. Nilai-nilai ketuhanan, kemanusiaan, persatuan dan kesatuan, permusyawaratan dan keadilan telah mengakar dalam jiwa bangsa Indonesia dan terlembaga dalam dasar negara (grundnorm) Pancasila.

Pancasila adalah bingkai terbaik sebagai rumah keragaman dan keberagamaan yang damai untuk mengayomi dan memberikan perlindungan atas

Maha Esa, dengan demikian, terbukalah kebebasan bagi warga negara untuk memeluk agama dan kepercayaan sesuai keyakinan masing-masing. Lihat: Arief Hidayat, "Negara Hukum Pancasila (Suatu Model Ideal Penyelenggaraan Negara Hukum), Prosiding Kongres Pancasila IV (Yogyakarta: PSP Universitas Gadjah Mada, 2012), h. 61.

${ }^{20}$ Pahom Narendra adalah Dewan Raja yang terdiri dari ayah, ibu, saudara-saudari dan ipar-ipar raja. Dewan ini bersidang untuk membicarakan hal-hal yang penting saja. Sepanjang pemerintahan Hayamwuruk telah bersidang 3 kali, yaitu membicarakan pembangunan caitia untuk memperingati para Pahlawan Singosari yang gugur besama Kertanegara (1351), membicarakan rencana perkawinan Hayamwuruk dengan putri Padjajaran (1359), dan membicaakan pengganti Gajah Mada yang meninggal dunia (1364). Lihat: P.J. Suwarno, Pancasila Budaya Bangsa Indonesia: Penelitian Pancasila dengan Pendkatan Historis, Filosofis dan Sosio-Yuridis (Yogyakarta: Kanisius, 1993), h. 21.

21 Ibid., h. 22-24. 
kebhinnekaan NKRI. Selama ini, Pancasila telah mampu mengkomunikasikan dan mendialektikkan berbagai suku, budaya dan agama, sehingga nasionalisme sempit yang berdasarkan sukuisme, radikalisme agama, chauvinisme maupun bentuk-bentuk anomali lainnya terhadap nasionalisme dan perasaan kebangsaan mampu dihindarkan.

Pancasila adalah grundnorm yang merupakan cita hukum Indonesia (rechtidee) dan landasan dalam pembentukan hukum. Pancasila bersifat meta juristic yang menjadi norma dasar tertinggi. Grundnorm bersifat abstrak, diasumsikan oleh daya akal budi manusia, tidak tertulis dan mempunyai daya keberlakuan universal dan tertinggi bagi tatanan hukum positif, walaupun keberadaannya tidak masuk dalam tatanan hukum positif.22 Kedudukan Pancasila sebagai grundnorm ${ }^{23}$, berada di atas Staat Grundgesetz (Aturan Dasar Negara);24 Formal Gesetz (Undang-Undang Formal); dan Verordnung en autonome satzung (Peraturan Pelaksana). ${ }^{25}$

Menurut Hans Kelsen, hubungan antara norma yang mengatur pembentukan norma dari norma lainnya digambarkan sebagai hubungan "superordinasi". Kesatuan norma-norma ini ditunjukkan oleh fakta bahwa pembentukan norma yang lebih rendah ditentukan oleh norma yang lebih tinggi dan regressus ini diakhiri oleh suatu norma dasar yang menjadi dasar tertinggi validitas keseluruhan tata hukum dan membentuk kesatuan tata hukum. ${ }^{26}$

Pancasila adalah staat fundamental norm yang memiliki fungsi konstitutif dan fungsi regulatif.27 Menurut Muladi, “Pancasila adalah bintang pemandu untuk menguji dan memberikan arah pada hukum positif di Indonesia. Pancasila

\footnotetext{
22Jazim Hamidi, Revolusi Hukum Indonesia: Makna, Kedudukan dan Implikasi Hukum Naskah Proklamasi 17 Agustus 1945 dalam Sistem Ketatanegaraan RI (Yogyakarta: Citra Media, 2006), h. 66-67

${ }^{23}$ Norma dasar merupakan norma tertinggi dalam susunan sistem norma, tidak dibentuk oleh suatu norma yang lebih tinggi lagi, tetapi norma itu ditetapkan terlebih dahulu oleh masyarakat sebagai norma dasar yang merupakan gantungan bagi norma-norma yang berada di bawahnya. Jimly Assidiqie dan M. Ali Safa'at, Teori Hans Kelsen tentang Hukum (Jakarta: Konstitusi Press, 2006), h. 109.

${ }^{24}$ Aturan dasar negara/aturan pokok negara adalah kelompok norma hukum di bawah norma fundamentalnegara. Sirojudin, Fatkhurohman, dan Zulkarnain, Legislatif Drafting; Pelembagaan Metode Partisipatifdalam Pembentukan Peraturan Perundang-Undangan (Malang: Setara Press, 2015), h. 44.

${ }^{25}$ Hans Kelsen, Pengantar Teori Hukum, edisi terjemahan (Bandung: Nusamedia, 2012), h. 115-116.

${ }^{26}$ Hans Kelsen, Teori Hukum Murni: Dsar-dasar Ilmu Hukum Normatif-Deskriptif (Jakarta: Rimdi Press, 1995), h. 110-125.

27Teguh Prasetyo dan Arie Purnomosidi, Membangun Hukum Berdasarkan Pancasila (Bandung: Nusamedia, 2014), h. 36.
} 
menjadi margion of appreciation doctrine".28 Dengan demikian kedudukan Pancasila dalam pembangunan hukum sangat penting, karena di dalamnya terkandung nilai-nilai ideologis, yaitu nilai-nilai ideologi nasional yang terdapat dalam Pancasila; nilai-nilai historis, yaitu nilai-nilai lahir berdasarkan perjalanan sejarah bangsa Indonesia; nilai-nilai Sosiologis, yaitu nilai-nilai yang tumbuh bersama budaya masyarakat; nilai-nilai yuridis, yaitu nilai-nilai yang sesuai dengan peraturan perundang-undangan; dan nilai-nilai filosofis, yaitu nilai-nilai berlandaskan pada rasa keadilan dan kebenaran. ${ }^{29}$ Oleh karena itu, nilai-nilai yang terkandung di dalam Pancasila tidak ada yang bertentangan dengan nilainilai agama yang terkadung di dalam kitab suci. Sebagai paradigma pembangunan hukum, Pancasila menjadi pedoman dalam pembentukan hukum di Indonesia, yaitu: ${ }^{301}$ ) Hukum harus melindungi segenap bangsa dan menjamin keutuhan bangsa dan karenanya tidak boleh ada hukum yang menanamkan benih disintegrasi; 2) Hukum harus menjamin keadilan sosial dengan memberikan proteksi khusus bagi golongan lemah agar tidak tereksploitasi dalam persaingan bebas melawan golongan yang kuat; 3) Hukum harus dibangun secara demokratis sekaligus membangun demokrasi sejalan dengan negara hukum; 4) Hukum tidak boleh diskriminatif berdasarkan ikatan primordial apapun dan harus mendorong terciptanya toleransi beragama berdasarkan kemanusiaa dan keberadaban.

Dengan demikian, Pancasila adalah sebuah rumah untuk pluralisme. Oleh karena itu, untuk meyelesaikan persoalan yang berbasis keberagaman dan keberagamaan, pendekatan pluralistik sangat diperlukan. Pluralisme hukum adalah pendekatan yang paling tepat untuk mengatasi persoalan-persoalan ini. Pluralisme hukum menawarkan sebuah model berfokus pluralitas untuk memahami hukum dengan mempertimbangkan tiga elemen pokok, yaitu natural law(ethic/moral/religion), positive law, dan socio-legal. Terdapat interaksi yang konstan di antara tiga elemen tersebut ${ }^{31}$ Pluralisme hukum menempatkan pe-

\footnotetext{
${ }^{28} \mathrm{Ibid}$, , h. 156.

${ }^{29} \mathrm{Ibid}$, h. 148

30Moh. Mahfud MD., Membangun Politik Hukum, Menegakkan Konstitusi (Jakarta: Rajawali Press, 2010), h. 56.

31Werner Menski, Perbandingan Hukum dalam Konteks Global; Sistem Eropa, Asia dan Afrika, terj. (Bandung: Nusa Media, 2015), h. 244-247.
} 
mahaman hukum secara komprehensif dan holistik, agar tercapai keadilan substantif.

Menurut Suteki, legal pluralism merupakan strategi pendekatan baru untuk melakukan terobosan hukum melalui the non enforcement of law ${ }^{32}$ agar hukum dapat melakukan lompatan (rule breaking) ke arah pertimbangan living law dan natural law. ${ }^{33}$ Indonesia memiliki 4 (empat) sistem hukum, yaitu hukum adat, hukum agama (Islam), civil law system dan common law system. ${ }^{34}$ Hukum adat yang berlaku di Indonesia merupakan hukum asli yang lahir dan hidup dalam denyut nadi perkembangan masyarakat Indonesia (living law) yang berlaku sebagai law society. Sedangkan nilai-nilai yang terkandung dalam hukum agama berlaku sebagai natural law.

Persoalan-persoalan SARA dapat diselesaikan dengan pendekatan ini. Persoalan SARA tidak hanya diselesaikan dengan pendekatan positivistic (state positive law) saja, karena pada dasarnya peraturan perundang-undangan memiliki keterbatasan yang dapat berujung pada kebuntuan aturan, sedangkan dinamika masyarakat dan persoalannya semakin kompleks. Keadilan substantif akan urung didapatkan, bila keadilan hanya dicari melalui law in the books. Karena itulah, diperlukan sisi pendekatan lain yang dapat membantu mengungkapkan dan mengupayakan penyelesaian permasalahan ini adalah melalui socio-legal approach.

Masyarakat pada dasarnya telah memiliki pranatanya masing-masing dan semuanya itu hanya bisa ditemukan bila mencari aturannya di masyarakat (living law). Pranata-pranata yang ada di dalam masyarakat tumbuh sesuai karakteristik masyarakatnya. Ciri khas kesukuan, kedaerahan, budaya dan

32 The non enforcement of law adalah gagasan yang disampaikan oleh Suteki sebagai Guru Besar Ilmu Hukum dalam bidang Hukum dan Masyarakat. The non enforcement oflaw adalah gagasan tentang hukum yang tidak ditegakkan atau dalam bahasa vulgar berarti peraturan hukum yang dilanggar. Gagasan ini muncul; karena banyaknya peraturan perundang-undangan (over regulation) yang sudah dibuat, tetapi banyak juga dikeluarkan kebijakan-kebijakan untuk tidak memberlakukannya (non enforcement) karena suatu situasi tertentu, padahal hukum ditujukan untuk ditegakkan bukan sebaliknya dilanggar. Suteki, "Kebijakan Tidak Menegakkan Hukum (Non Enforcement of Law) Demi Pemuliaan Keadilan Substantif," Pidato Pengukuhan Guru Besar Universitas Diponegoro, Semarang, Universitas Diponegoro, 4 Agustus 2010, h. 2 dan 9.

${ }^{33}$ Suteki, Desain Hukum di Ruang Sosial (Yogyakarta: Thafa Media, 2013), h. 195-196.

34Teguh Prasetyo, Hukum dan Sistem Hukum Berdasarkan Pancasila (Yogyakarta: Media Perkasa, 2013), h. 75. 
agama sangat melekat pada bentuk pranata yang ada. Pranata inilah yang membingkai perilaku sekaligus perekat ikatan primordial yang ada di antara mereka. Hukum dalam bentuk pranata sosial yang kukuh dan kokoh dalam masyarakat inilah yang seringkali memiliki daya pembentuk perilaku yang kuat, diyakini, diikuti dan tumbuh bersama masyarakat yang ada. Sanksi sosial seringkali dinilai lebih pedih dari ujung mata tombak penegakan hukum formal oleh negara. Ikatan primordial seringkali dinilai lebih kuat membentuk komunal mereka. Hal ini disebabkan, "tiada pranata tanpa masyarakat, dan tiada masyarakat tanpa pranata". Brian Z. Tamanaha menyatakan bahwa "hukum dan masyarakat memiliki bingkai yang disebut dengan the law society framework yang memiliki hubungan tertentu".35

State positivism dan law society tidak boleh bebas nilai. Kehadiran hukum negara dan hukum yang hidup di masyarakat harus sarat nilai. Nilai-nilai moral, ethic dan keadilan tidak dapat dilepaskan dari hukum. Hukum tidak boleh tajam ke bawah dan tumpul ke atas. Hukum tidak boleh tebang pilih. Hukum juga tidak boleh diperjualbelikan untuk kepentingan tertentu. Hakim bukanlah corong undang-undang (la bouche de la loi) yang hanya menyatakan apa yang dinyatakan dalam pasal-pasalnya. Hakim berperan lebih dari itu. Hakim harus mampu menggunakan kecerdasan spiritual untuk berani mencari jalan baru yang dapat mewujudkan keadilan. Hakim harus mampu melakukan pencarian makna mendalam dengan hati nuraninya dan membuat ukuran baru dalam menjalankan hukum. Hukum dijalankan dengan prinsip kepedulian, perasaan, dan keterlibatan kepada kelompok yang lemah. ${ }^{36}$

Hukum memiliki hubungan langsung dengan manusianya, hukum tidak berjarak dengan manusia. Prinsipnya, hukum adalah untuk manusia, bukan manusia untuk hukum. Hukum bukan sesuatu yang absolut dan final,37

\footnotetext{
${ }^{35}$ Brian Z. Tamanaha, A General Jurisprudence of Law and Society (New York: Oxford University Press, 2006), h. 1-2.

36Satjipto Rahardjo, "Hukkum Progresif: Hukum yang Membebaskan”, Jurnal Hukum Progresif, Vol. 1, No. 1, April 2005, PDIH Undip, Semarang, h. 5.

${ }^{37}$ Satjipto Rahardjo menyatakan bahwa hukum selalu berada dalam proses menjadi. Hukum adalah institusi yang secara terus menerus membangun dan mengubah dirinya menuju pada tingkatan kesempurnaan yang lebih baik. Hakikat hukum adalah law as a process, law in the making. Hukum yang demikian ini disebut dengan hukum progresif. Lihat: Satjipto Rahardjo, Hukum Progresif: Sebuah Sintesa Hukum Indonesia (Yogyakarta; Genta Publishing, 2009), h. 2-6.
} 
melainkan sangat bergantung pada bagaimana manusia melihat dan menggunakannya. ${ }^{38}$ Hukum dibuat oleh manusia, dilaksanakan oleh manusia dan untuk mengatur kehidupan manusia. Hakim, polisi, jaksa, advokat dan penegak hukum lainnya adalah manusia. Para pembuat hukum di legislatif dan eksekutif juga manusia, demikian juga masyarakat yang diatur oleh hukum. Karena itu, state positivism dan law society dipandu oleh moral, ethic dan religion (natural law), sebagaimana legal pluralism yang disampaikan oleh Werner Menski dalam Bagan 1.

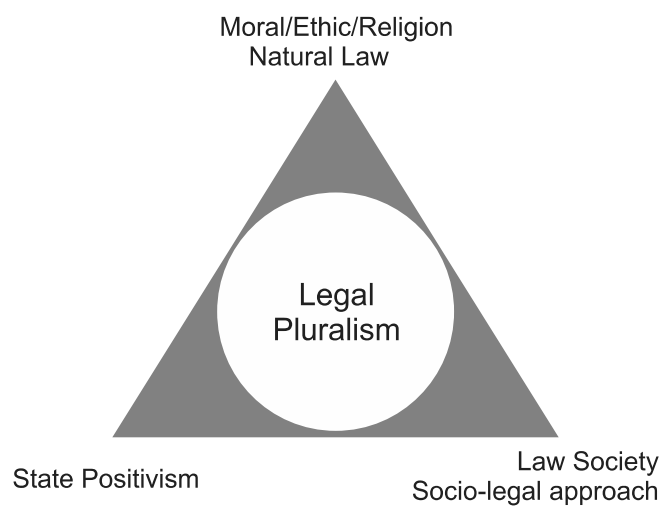

Bagan 1. Legal Pluralism

Bagan ini menjelaskan bahwa dunia hukum memiliki dimensi sangat plural dan tidak dapat dibatasi oleh ruang dan waktu. Tidak dapat dibentuk hanya dengan satu dimensi saja, namun ada keterkaitan antar dimensi, yaitu state positivism, society dan natural law. Ketiga sudut dimensi ini tidak akan mampu menyerap keseluruhan dimensi pluralitas hukum yang ada di masyarakat. Masyarakat adalah kumpulan manusia yang memiliki entitas moral dengan dipandu religiusitas masing-masing. Di sisi lain, manusia juga menjadi bagian dari masyarakat dan karakteristik yang mengkonstruksikannya dan di lain pihak, masyarakat juga merupakan bagian dari entitas negara yang tidak dapat lepas dari state positive law. Legal pluralisme berusaha menyerap ketiga

${ }^{38}$ Faisal, Memahami Hukum Progresif (Yogyakarta; Thafamedia, 2014), hlm., 54. Lihat juga dalam Faisal, Menerobos Positivisme Hukum (Jakarta: Gamata Publishing, 2012), h. 101-102. 
dimensi tersebut dalam satu lingkaran formalisasi hukum yang berlaku bagi masyarakat sebagai individu, bagian dari masyarakat sekaligus sebagai bagian dari warga negara yang tunduk pada hukum negara yang berlaku. Namun demikian, lingkaran pluralisme hukum yang dibuat tetap tidak mampu menyerap residu pluralisme yang ada pada masing-masing dimensi dan meletakkannya tetap pada masing-masing dimensi sebagai kekuatan yang tidak dapat diabaikan.

Persoalan keberagaman dan keberagamaan yang ada di Indonesia adalah bagian dari kompleksitas masyarakat prismatik dan pluralistik. Masyarakat Indonesia memiliki karakteristik yang berada dalam ketiga dimensi tersebut. Masyarakat Indonesia adalah masyarakat yang ber-Ketuhanan Yang Maha Esa yang dipandu oleh agama dan kepercayaan masing-masing. Moralitas dan nilainilai ethic religion tumbuh bersama dengan keyakinan dan kepercayaan masyarakat Indonesia. Semua agama dan kepercayaan saling berdialektika dalam rumah Pancasila, mendialogkan nilai-nilai luhur ajaran agama. Semua nilai luhur di dalam ajaran agama bersesuaian dan Pancasila mampu mewadahinya untuk selanjutnya diikat dalam bingkai Negara Kesatuan Republik Indonesia.

Di dalam rumah Pancasila, semua umat beragama, suku dan seluruh masyarakat saling menjaga harmonisasi dan menahan diri untuk tidak menonjolkan agama dan/atau etnisnya masing-masing, namun lebih mengedepankan persatuan dan kesatuan bangsa dalam NKRI,39 sebagaimana disampaikan oleh Soepomo:

Maka semangat kebatinan struktur kerohanian dari bangsa Indonesia bersifat an bercita-cita persatuan hidup, persatuan kawulo dan gusti, yaitu persatuan

\footnotetext{
${ }^{39}$ Dapat dilihat pada saat Sidang Pleno BPUPKI tanggal 10 Juli 1945 telah dirumuskan sebuah modus antara golongan Islam dan golongan kebangsaan yang dicantumkan dalam suatu rancangan pembukaan hukum dasar yang disampaikan oleh Panitia Kecil kepada sidang pleno BPUPKI yang kedua, yaitu " ... dengan berdasar kepada Ketuhanan dengan kewajiban menjalankan syariat Islam bagi pemeluk-pemeluknya, menurut dasar kemanusiaan yang adil dan beradab, persatuan Indonesia dan kerakyatan yang dipimpin oleh hikmat kebijaksanaan dalam persmusyawaratan perwakilan serta dengan mewujudkan suatu keadilan sosial bagi seluruh rakyat Indonesia". Pernyataan sila I ini diprotes oleh banyak kalangan. Puncaknya adalah ketika di preamble konstitusi akan dikukuhkan pada tanggal 18 Agustus 1945. Wakil Protestan dan Katholik keberatan dengan bunyi sila I dan meminta untuk diubah karena mengancam akan membangun negara sendiri di luar NKRI. Selanjutnya, bunyi Sila I diubah menjadi "Ketuhanan Yang Maha Esa", demi persatuan dan kesatuan bangsa. Pancasila yang terdapat dalam preamble konstitusi adalah modus kompromi antar golongan nasionalis, golongan Islam dan Kristen-Katholik. Lihat: P.J. Suwarno, Pancasila Budaya Bangsa Indonesia...., h. 71-79.
} 
antara dunia luar dan dunia batin, antara mikrokosmos dan makrokosmos, antara rakyat dan pemimpin-pemimpinnya. Segala manusia sebagai seseorang, golongan manusia dalam suatu masyarakat dan golongan-golongan lain dari masyarakat itu dan tiap-tiap masyarakat dalam pergaulan hidup di dunia seluruhnya dianggapnya mempunyai tempat dan kewajiban hidup (dharma) sendiri-sendiri menurut kodrat alam dan segala-galanya ditujukan kepada keseimbangan lahir dan batin. Manusia sebagai seseorang yang tidak terpisah dengan seseorang lain atau dari dunia luar, golongan-golongan manusia, bercampur-baur dan bersangkut paut, berpengaruh-pengaruhi. Inilah ide totaliter, ide integralistik dari bangsa Indonesia yang berwujud dalam susunan tatanegaranyayang asli. ${ }^{40}$

Komitmen kebangsaan di dalam konstistusi sudah sangat jelas, bahwa Indonesia bukan negara agama sekaligus bukan negara tanpa agama. Indonesia adalah religious nation state dalam kerangka Negara Kesatuan Republik Indonesia. Persoalan-persoalan yang timbul karena gesekan-gesekan keberagaman dan keberagamaan tidak bisa diselesaikan dengan tekanan dominasi mayoritas terhadap minoritas atau hanya dengan state law enforcement. Benihbenih kebencian justru akan tumbuh subur karena rasa sakit hati bila putusan pengadilan hanya mengedepankan sisi menang dan kalah, bukan benar dan salah. Rekonsiliasi dan pendekatan natural law dan law society sangat diperlukan.

Pendekatan natural law dapat ditempuh melalui para pemuka agama yang duduk bersama berekonsiliasi mengupayakan pembenahan ke dalam, dalam arti menasihatkan dan menyampaikan isi kitab suci kepada umat beragamanya tentang kebaikan hidup, toleransi, hidup bermasyarakat dan menghindarkan diri dari upaya pecah belah yang akan melemahkan perasaan kebangsaan. Lintas pemuka agama juga dapat menyampaikan kepada masyarakat luas akan empati dan keprihatinannya akan tercederainya rasa persatuan dan kesatuan, serta bergandeng tangan mengupayakan kembali integrasi bangsa.

Demonstrasi adalah bagian dari law society karena tercederainya keberagaman dan keberagamaan yang selama ini diharmonisasikan. Penyampaikan aspirasi secara damai adalah bagian dari menjaga persatuan dan kesatuan bangsa. Komunikasi dan rekonsiliasi antara umat beragama, pemuka agama dan kehadiran negara (state positivism law) sangat diperlukan. Dialektika harus dibangun di antara umat beragama, pemuka agama dan pemerintah. Dialektika

40Ibid., h. 45. 
pluralisme hukum juga harus hadir, untuk mensinergikan penyelesaian persoalan, tidak hanya dari satu dimensi state positivism law saja, namun juga law society dan kembali pada nilai-nilai moralitas ethic religion.

\section{Kesimpulan}

Berdasarkan pembahasan atas permasalahan dalam kajian ini, dapat disimpulkan bahwa pluralitas masyarakat harus dipahami dengan menggunakan pendekatan yang tepat juga, yaitu legal pluralism, jangan sampai keragaman dan kebaragamaan justru tercederai karena penyelesaian persoalan menggunakan dimensi pemahaman hukum yang tidak tepat. Persoalan SARA yang timbul dapat dilihat dari tiga dimensi yang berbeda dan dapat disinergikan, yaitu dengan pendekatan natural law, law society dan state positivism. Para pemuka agama dapat menggunakan pendekatan natural law untuk reinternaliasasi nilai-nilai keluhuran atas agama dan toleransi. Pemerintah juga harus melihat secara arif bahwa gerakan-gerakan protes atas penistaan agama dan etnis muncul seiring dengan tercederainya keragaman dan keberagamaan di dalam masyarakat. Gerakan-gerakan tidak hanya diantisipasi kemungkinan akan mengakibatkan kerusuhan dan anarkisme, namun juga membantu mengawal sampai aspirasi dapat disampaikan dengan damai dan didengar oleh pimpinan negeri. Penegakan hukum sebagai bentuk bekerjanya state positivism law juga dikawal pelaksanaannya agar tidak terintevensi oleh kepentingan tertentu sehingga dapat mengakibatkan kehancuran bangsa. State positivism law harus mampu menggandeng natural law dan law society, agar diperoleh putusan terbaik yang berlandaskan nilai-nilai moral ethic religion dan berlandaskan nilai-nilai sosial kemasyarakatan.[w] 


\section{BIBLIOGRAFI}

Alwasilah, A. Chaedar, Pokoknya Kualitatif: Dasar-dasar Merancang dan Melakukan Penelitian Kualitatif, Bandung: Dunia Pustaka Jaya, 2012

Assidiqie, Jimly, dan Safa'at, M. Ali, Teori Hans Kelsen tentang Hukum, Jakarta: Konstitusi Press, 2006.

Denzin, Norman K. dan Lincoln, Yvonna S., Handbook of Qualitative Research, edisi terjemahan, Yogyakarta: Pustaka Pelajar, 2009.

Dewi, Ita Mutiara, "Nasionalisme dan Kebangkitan dalam Teropong", Jurnal Mozaik, Vol. 3 No. 3, Tahun 2008.

Faisal, Memahami Hukum Progresif, Yogyakarta: Thafamedia, 2014.

Menerobos Positivisme Hukum, Jakarta: Gamata Publishing, 2012.

Hidayat, Arief, "Negara Hukum Pancasila (Suatu Model Ideal Penyelenggaraan Negara Hukum), Prosiding Kongres Pancasila IV, Yogyakarta: PSP Universitas Gadjah Mada, 2012.

Hamidi, Jazim, Revolusi Hukum Indonesia: Makna, Kedudukan dan Implikasi Hukum Naskah Proklamasi 17 Agustus 1945 dalam Sistem Ketatanegaraan RI, Yogyakarta: Citra Media, 2006.

Hasan, M. Iqbal, Pokok-pokok Materi Metodologi Penelitian dan Aplikasinya, Jakarta: Ghalia Indonesia, 2002.

https://www.youtube.com/watch?v=dkeOkOmd6_Y. diunduh tanggal 19 Oktober 2016.

https://www.intelijen.co.id/lakukan-penistaan-agama-muhammadiyahsegera-polisikan-ahok/. Diunduh 19 Oktober 2016,

http://berita.islamedia.id/2016/10/inilah-fatwa-lengkap-mui-ahok-terbuktimenghina-alquran-ulama.html. diunduh 19 Oktober 2016.

http://news.okezone.com/read/2016/10/14/338/1514795/demo-ahok-50ribu-anggota-ormas-islam-turun-ke-jalan. diunduh 19 Oktober 2016.

Kelsen, Hans, Pengantar Teori Hukum, edisi terjemahan, Bandung: Nusamedia, 2012. 
Teori Hukum Murni: Dasar-dasar Ilmu Hukum Normatif-Deskriptif, Jakarta: Rimdi Press, 1995.

Kesbangpol Kementrian Dalam Negeri Tahun 2013, 2014 dan kuartal 2015. http://kesbangpol.kemendagri.go.id/files_uploads/Data_Konflik.pdf.

Latif, Yudi, "Revitalisasi Pancasila di Tengah Dua Fundamentalisme", Jurnal Dignitas, Vol. VII, No.2 Tahun 2011.

MD., Moh. Mahfud, Membangun Politik Hukum, Menegakkan Konstitusi, Jakarta: Rajawali Press, 2010.

Menski, Werner, Perbandingan Hukum dalam Konteks Global: Sistem Eropa, Asia dan Afrika, edisi terjemahan, Bandung: Nusa Media, 2015.

Moleong, Lexy J., Metodologi Penelitian Kualitatif, Bandung: Remaja Rosdakarya, 2004.

Prasetyo, Teguh, Hukum dan Sistem Hukum Berdasarkan Pancasila, Yogyakarta: Media Perkasa, 2013.

Prasetyo, Teguh, dan Purnomosidi, Arie, Membangun Hukum Berdasarkan Pancasila, Bandung: Nusamedia, 2014.

Purwodarminto, Kamus Umum Bahasa Indonesia, Jakarta, Balai Pustaka, 1978.

Rahardjo, Satjipto, "Hukum Progresif: Hukum yang Membebaskan", Jurnal Hukum Progresif, Vo. 1, No. 1, April 2005, PDIH Undip, Semarang, 2005.

Hukum Progresif: Sebuah Sintesa Hukum Indonesia, Yogyakarta: Genta Publishing, 2009.

Sidharta, Bernard Arief, Ilmu Hukum Indonesia, Upaya Pengembangan Ilmu Hukum Sistematik yang Responsif terhadap Perubahan Masyarakat, Yogyakarta: Genta Publishing, 2013.

Sirojudin, Fatkhurohman, dan Zulkarnain, Legislatif Drafting: Pelembagaan Metode Partisipatif dalam Pembentukan Peraturan Perundang-Undangan, Malang: Setara Press, 2015.

Desain Hukum di Ruang Sosial, Yogyakarta: Thafa Media, 2013.

Suteki, “Kebijakan Tidak Menegakkan Hukum (Non Enforcement of Law) Demi Pemuliaan Keadilan Substantif," Pidato Pengukuhan Guru Besar Universitas Diponegoro, Semarang, 4 Agustus 2010.

Suwarno, P.J., Pancasila Budaya Bangsa Indonesia: Penelitian Pancasila dengan Pendkatan Historis, Filosofis dan Sosio-Yuridis, Yogyakarta: Kanisius, 1993. 
Tamanaha, Brian Z., A General Jurisprudence of Law and Society, New York: Oxford University Press, 2006.

Tashakkori, Abbas, dan Charles Tedlie, Mixed Methodology: Mengkombinasikan Pendekatan Kualitatif dan Kuantitatif, Yogyakarta: Pustaka Pelajar, 2010.

Wibowo, J. Indowan Seto Wahyu, "Representasi Terorisme di Indonesia dalam Pemberitaan Media Massa: Kritik Pemberitaan Terorisme pada Koran Tempo 2010)", Disertasi, tidak diterbitkan, Jakarta: Fakultas Ilmu Sosial dan Ilmu Politik, Universitas Indonesia, 2014.

Wignjosoebroto, Soetandyo, "Penelitian Hukum dan Hakikatnya sebagai Penelitian Ilmiah", dalam Sulistyowati Irianto dan Sidharta, Metode Penelitian Hukum, Konstelasi dan Refleksi, Jakarta: Yayasan Obor Indonesia, 2009. 